\title{
Investigation of Antioxidant Properties on Some Garlic Varieties and Influence of Farming Inputs on the Quality of Garlic
}

\author{
Ulyatu Fitrotin ${ }^{1}$, Baiq Nurul Hidayah ${ }^{2 *}$ \\ 1 Post Harvest Research Division, Institute for Assessment of Agricultural Technology (IAAT), West Nusa \\ Tenggara Province, Indonesia. \\ ${ }^{2}$ Crop and Livestock Research Division, Institute for Assessment of Agricultural Technology (IAAT), West \\ Nusa Tenggara Province, Indonesia. \\ * Corresponding author. Tel.:+6281238510660; email: baiqnurul@pertanian.go.id \\ Manuscript submitted January 10, 2019; accepted March 8, 2019. \\ doi: 10.17706/ijbbb.2019.9.3.180-187
}

\begin{abstract}
The antioxidant activities of garlic are influenced by its variety and farming practices. The objectives of this research were to determine the phenolic compounds and antioxidant activities of garlic varieties which were marketed in Indonesia. The phenolic compounds were determined with Folin-Ciocalteu and antioxidant activities were examined using 2,2-diphenyl-2-phicrylhydrazyl (DPPH). Ascorbic acid was used as antioxidant reference. In this experiment, nine garlic varieties from different region in the world, as well as in Indonesia were investigated. Those varieties were Chinese, Egyptian, Indian, Sangga Sembalun (purple), Sangga Sembalun (white), Sangga Nunggal, Lumbu Kuning, Lumbu Hijau, and Ncuna Sambori. The results showed that antioxidant activities of Lumbu Hijau, Sangga Sembalun (white) and Ncuna Sambori were among the highest but not different statistically $(p<0.05)$. Moreover, Sangga Sembalun (purple), Lumbu Kuning, Indian, Sangga Nunggal and ascorbic acid 15 ppm (as comparison) were in the second level and not different statistically $(p<0.05)$, while Chinese and Egyptian varieties were the lowest. Sangga Sembalun (white) variety was further cultivated with different dose of farming inputs (manure, dolomite, NPK, SP-36, ZA, Urea and KCl). Results showed that the antioxidant activities of Sangga Sembalun (white) which was cultivated with different dose of farming inputs were not different statistically $(p<0.05)$. In general, different dose of farming inputs in farming practices were not changed the antioxidant activities of garlic variety.
\end{abstract}

Key words: Antioxidant activities, garlic varieties, phenolic compounds.

\section{Introduction}

Garlic (Allium sativum L.) is one of the horticultural commodities with a very high economic value. It is a very important horticultural product for Indonesian people because it is used as a cooking spice, medicine and cosmetic ingredients [1]. The national demand of garlic in Indonesia is currently estimated at 500,000 tons per year, and can only be fulfilled by domestic production of 20,000 tons [2]. This caused the number of imported garlic to reach 480,000 tons (around 96\%). This condition resulted that many varieties of garlic circulating in the market both local markets and supermarkets. Imported garlic varieties such as variety from China, Egypt and India, and local varieties such as Sangga Sembalun (white), Sangga Sembalun (purple), Sangga Nunggal, Lumbu Kuning, Lumbu Hijau and Ncuna Sambori can be found at markets in West Nusa Tenggara Province of Indonesia. 
Garlic has been cultivated in various regions in Indonesia. Varieties of garlic that is often found in Indonesia is Lumbu Hijau and Lumbu Kuning. Several varieties of garlic can also be found in various regions in Indonesia. However, other varieties are thought to originate from the same source due to modifications from existing sources. Because garlic is propagated with tubers continuously, a very large mutation may occur which will change the properties of garlic. The Santong variety in Lombok Island of Indonesia, for example, is similar to the Lumbu Hijau variety while the Tawangmangu and Cirebon varieties are similar to the Lumbu Kuning variety [3].

Garlic is known to contribute greatly to health and many benefits for a long time. This is because garlic contains bioactive compounds that can act as antioxidants and have a strong aroma that is widely used in various cuisines [4]. The volatile components found in garlic are mostly sulfur compounds. The sulfur component contained in garlic not only gives a distinctive flavor but also has several properties as bioactive compounds. The amount of sulfur compounds in garlic is influenced by varieties, maturity, cultivation techniques, and environmental conditions [5]. There is no definitive information on varieties that have high antioxidant properties yet on garlic in Indonesia.

Sembalun Highland in Lombok Island of West Nusa Tenggara Province is one of the centers of garlic in Indonesia (Fig. 1). Since 1997 until 2017 stretching of garlic cultivation in the region has declined due to imported garlic at very cheap prices therefore garlic which produced in Sembalun Highland could not compete. In the last few years, the cultivation of garlic was revived by the Indonesian government through the Ministry of Agriculture. The objectives of this research were to determine the antioxidant activities and phenolic compounds of garlic varieties which are marketed in Indonesia as well as to investigate the antioxidant activities of garlic harvested from different dose of farming inputs.

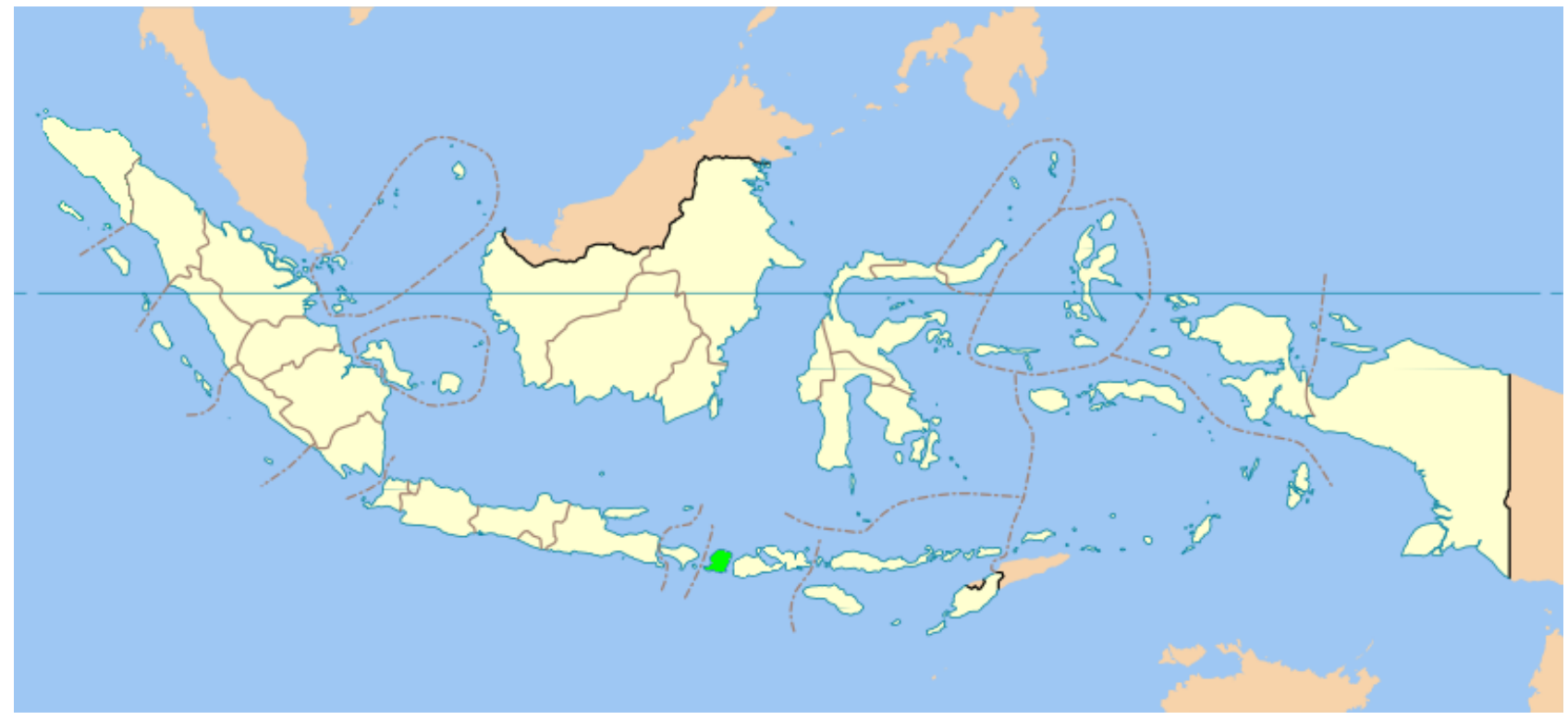

Fig. 1. Map of the Republic of Indonesia where Lombok Island is in the green colour below the map.

\section{Materials and Methods}

\subsection{Materials and Reagents}

Local and imported garlic varieties which were purchased from local market in West Nusa Tenggara Province of Indonesia; Folin Ciocalteu's reagent, ascorbic acid, 1,1-diphenyl-2-picrylhydrazyl (DPPH) (Sigma Chemical Co.-Aldrich, St. Louis, MO, USA), local cow manure, dolomite, chemical fertilizers (NPK, SP-36, ZA, Urea, $\mathrm{KCl}$ ), and chemical pesticides. 


\subsection{Preparation and Extraction of Fresh Garlic Extract}

Extraction of fresh garlic was done according to [6] with slight modification. The fresh garlic cloves were peeled from the bulb and ground by a hugh-speed blender. The ground BG was mixed with deionized water for $1 \mathrm{~h}$ at room temperature in a shaker (CR300, Fine PCR, Seoul, Korea). The extracts were centrifuged (400 rpm, $10 \mathrm{~min}$ ) and supernatant were collected. Finally the supernatant was analyzed as soon as possible (Fig. 2 and 3).

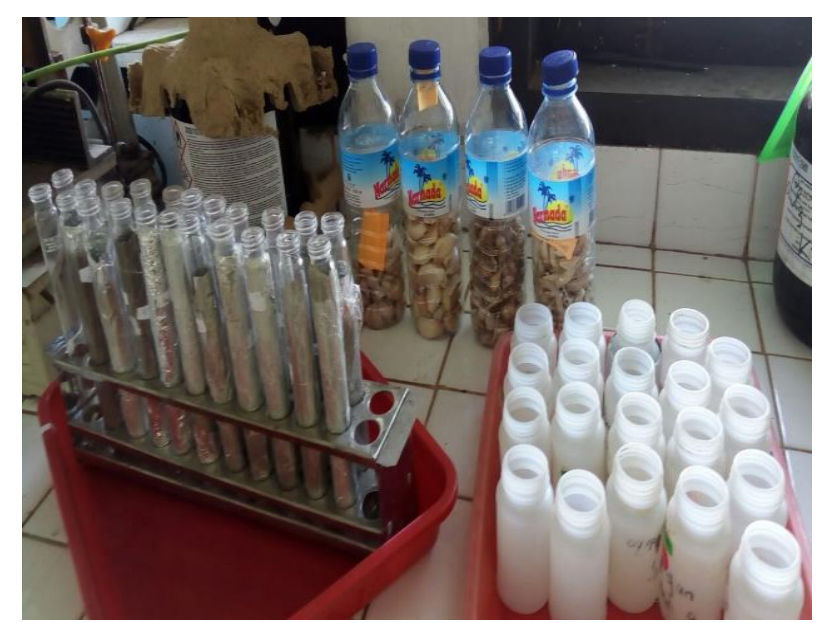

Fig. 2. Pre-extraction of fresh garlic at the IAAT Laboratory.

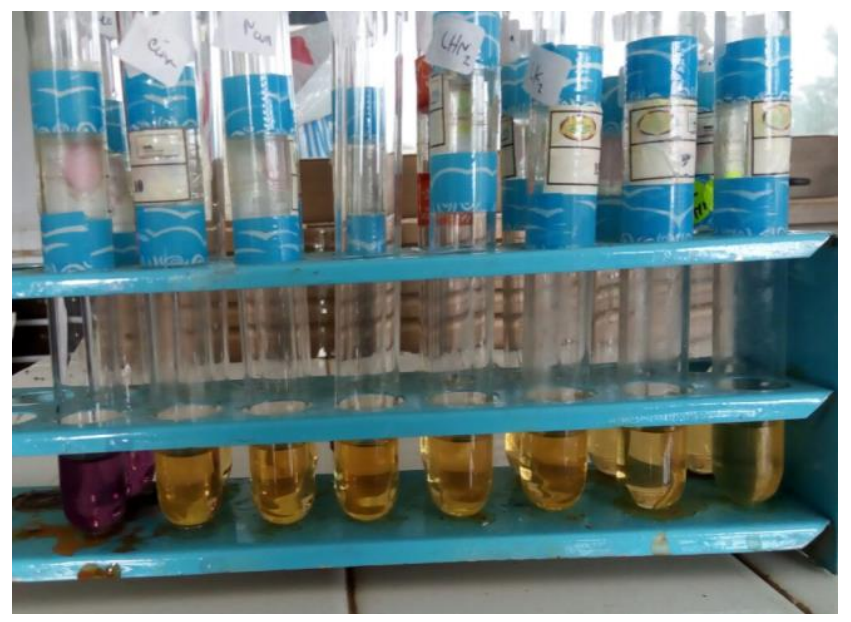

Fig. 3. Samples absorbance compared with control absorbance.

\subsection{DPPH Radical Scavenging Activity}

DPPH radical scavenging activity was determined according to [7]. DPPH solution in methanol (1.5 mM) was prepared, and then $3 \mathrm{ml}$ DPPH solution was mixed with $1 \mathrm{ml}$ crude extract of fresh garlic. The mixtures were incubated for $1 \mathrm{~h}$ in the dark room. Shimadzu UV-1601 spectrophotometer (Shimadzu, Kyoto, Japan) was used to measure the absorbance at $\lambda 524 \mathrm{~nm}$. The increasing of DPPH radical scavenging activity was shown by decreasing of the DPPH solution absorbance. The equation to calculate antioxidant activity was given as per cent DPPH radical scavenging activity. The control contained $3 \mathrm{ml}$ of $1.5 \mathrm{mM}$ DPPH solution and $1 \mathrm{ml}$ of methanol. Ascorbic acid was used as positive controls. Data were reported as means \pm SD for three replications.

$$
\operatorname{RSA}(\%)=\left[\frac{\text { control absorbance-sample absorbance }}{\text { control absorbance }}\right] \times 100 \%
$$




\subsection{Determination of Total Phenolic Content}

The crude extract $(2 \mathrm{ml}$ ) was placed in a tube, and $1 \mathrm{ml}$ Folin-Ciocalteu reagents was added, mixed, and allow to stand for $1 \mathrm{~min}$. Then $4 \mathrm{ml}$ of $15 \%$ of sodium carbonate $\left(\mathrm{Na}_{2} \mathrm{CO}_{3}\right)$ solution were added, mixed and placed in a dark room for $2 \mathrm{~h}$ at room temperature [8]. Absorbance of the resulting blue complex was then measured at $760 \mathrm{~nm}$ using a shimadzu UV-1601 spectrophotometer (Shimadzu, Kyoto, Japan). Methanol was used as the blank and gallic acid used as standard. The used of gallic acid based on its stability and purity. The results were expressed as mg gallic acid equivalents (GAE)/g of garlic. Data were reported as means \pm SD for three replications. All of laboratory experiments were conducted at the laboratory of IAAT, West Nusa Tenggara Province of Indonesia from February to August 2018.

\subsection{Field Experiment}

Field experiment was conducted at Sembalun Highland (1200 masl) in Lombok Island of Indonesia from February to June 2018 to investigate the influence of different dose of farming inputs toward antioxidant activities of harvested garlic. The experimental design was used Randomized Completely Block Design (RCBD) consisting of four blocks of experiment. Each block consisted of four treatments, namely: 1) Existing technology which was used by farmers (P1); 2) Technological Package I (P2); 3) Technological Package II (P3); and 4) Technological Package III (P4). Each treatment was repeated four times therefore there were sixteen plots of treatment. The details of technological packages which were applied are shown in Table 1. Furthermore, the position of each technological package inside the blocks is shown in Table 2.

Table 1. Technological Packages Which Were Applied in the Field Experiment during the Growing Season in 2018

\begin{tabular}{|c|c|c|c|c|}
\hline \multirow{2}{*}{ Inputs } & \multirow{2}{*}{$\begin{array}{l}\text { Existing Technology } \\
\text { (P1) }\end{array}$} & \multicolumn{3}{|c|}{ Technological Packages } \\
\hline & & (P2) & (P3) & (P4) \\
\hline Dolomite (kg/ha) & 500 & 1,000 & 500 & 250 \\
\hline Cow manure (kg/ha) & 4,000 & 10,000 & 5,000 & 2,500 \\
\hline NPK 16:16:16 (kg/ha) & 400 & 300 & 200 & 100 \\
\hline SP-36 (kg/ha) & 300 & 250 & 200 & 150 \\
\hline ZA (kg/ha) & 200 & 150 & 100 & 50 \\
\hline Urea (kg/ha) & 100 & 100 & 75 & 50 \\
\hline $\mathrm{KCl}$ (kg/ha) & 100 & 100 & 75 & 50 \\
\hline Pest control & $\begin{array}{l}\text { Existing technology (mixing } \\
\text { pesticides as usual used by } \\
\text { farmers) }\end{array}$ & $\begin{array}{c}\text { Spraying } \\
\text { pesticides based } \\
\text { on rotation } \\
\text { strategies }\end{array}$ & $\begin{array}{c}\text { Spraying } \\
\text { pesticides based } \\
\text { on rotation } \\
\text { strategies }\end{array}$ & $\begin{array}{c}\text { Spraying } \\
\text { pesticides } \\
\text { based on } \\
\text { rotation } \\
\text { strategies }\end{array}$ \\
\hline
\end{tabular}

Table 2. The Experimental Design in the Field Experiment at Sembalun Highland in Lombok Island of Indonesia during the Growing Season in 2018

\begin{tabular}{|l|l|l|l|}
\hline \multicolumn{9}{|c|}{ BLOCK } \\
\hline I & II & III & IV \\
\hline P3 & P1 & P4 & P2 \\
\hline P1 & P2 & P3 & P4 \\
\hline P4 & P3 & P2 & P1 \\
\hline P2 & P4 & P1 & P3 \\
\hline
\end{tabular}

The land area of 0.4 ha was divided into four replication blocks of 0.1 ha each, in each replication block there are four treatment packages (P1 -P4). Garlic variety which were used for field experiment was local 
variety namely Sangga Sembalun (white). Fig. 5-7 showed some photos taken from field experiment during growing season 2018 in Sembalun Village, Sub District of Sembalun, District of East Lombok, West Nusa Tenggara Province of Indonesia.

\subsection{Statistical Analysis}

Data which were collected during laboratory and field experiments were analysed with SPSS version 12.0 using one way ANOVA followed by least significant different (LSD) test at the $95 \%$ confident level.

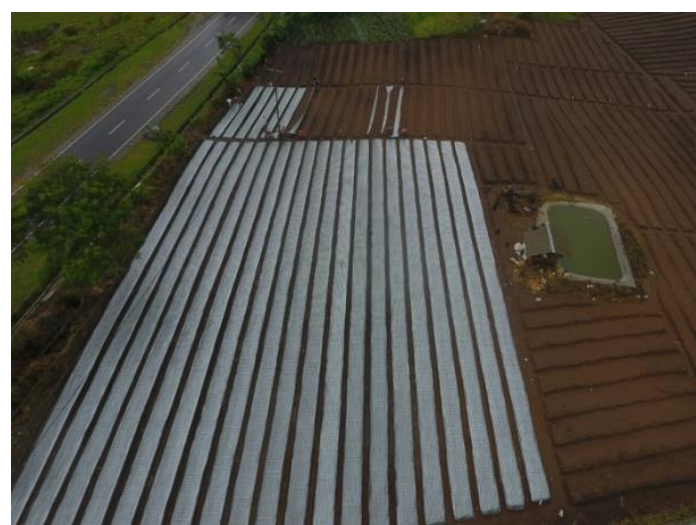

Fig. 4. The selected site for field experiment in 2018 at Sembalun Highland of Lombok Island, Indonesia.

Photo taken after soil tillage and during installation of plastic mulch in February 2018.

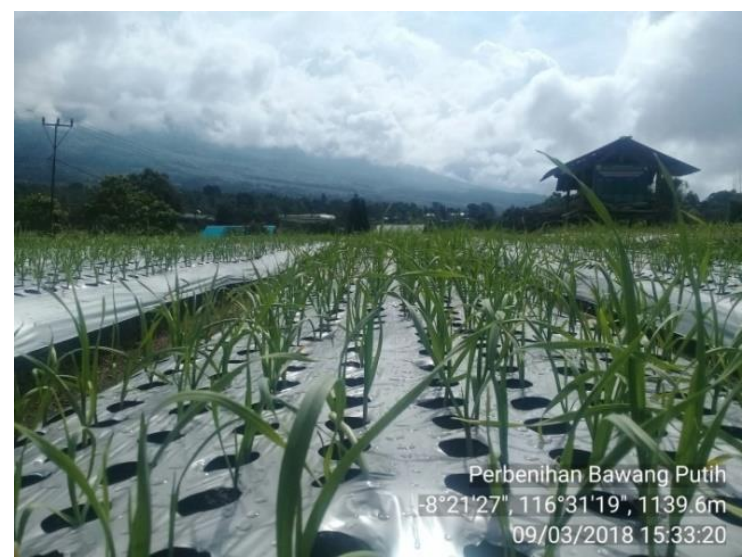

Fig. 5. Early vegetative phase of garlic crop during field experiment in 2018 at the Sembalun Highland experimental site at 19 days after sowing.

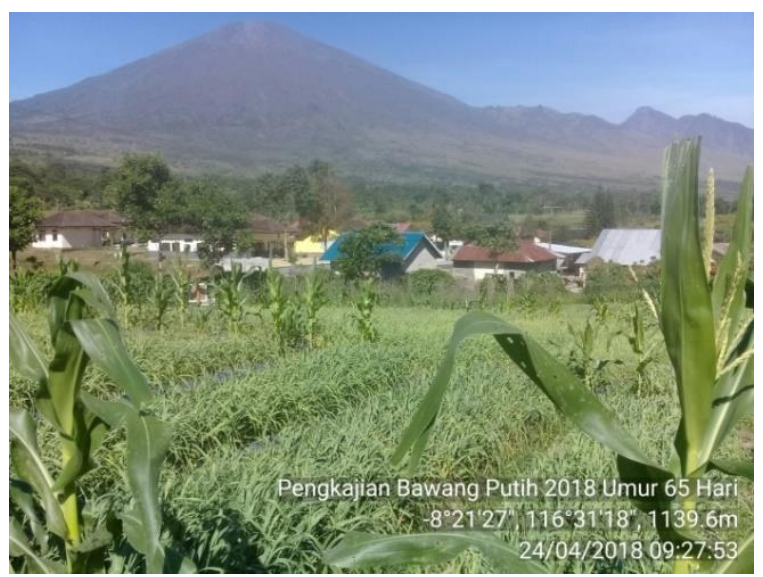

Fig. 6. Performance of garlic crop at the Sembalun Highland experimental site during field experiment in 2018 at 65 days after sowing. 


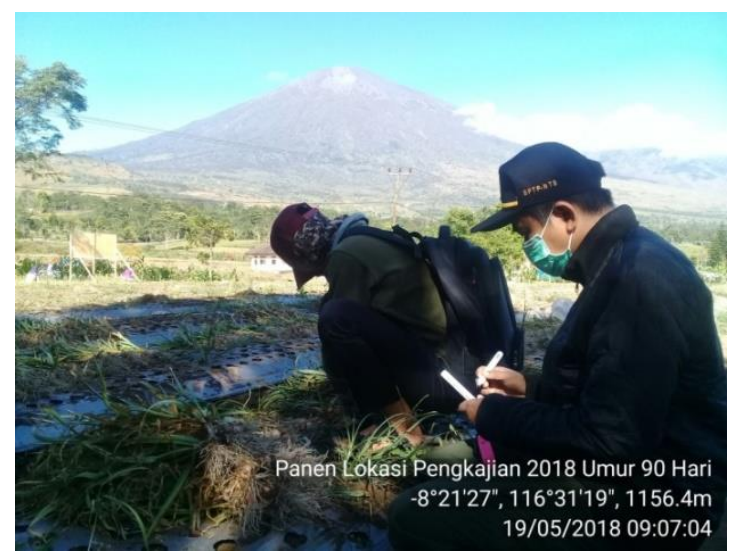

Fig. 7. Harvesting of garlic crop at the Sembalun Highland experimental site during field experiment in 2018 at 90 days after sowing.

\section{Results and Discussion}

The diversity of \% radical scavenging activity is thought to be influenced by the genetic traits of each plant that are influenced by the conditions of the niche of cultivation. One example of Lumbu Hijau garlic leaves has a darker color than Lumbu Kuning garlic leaves. This causes the Lumbu Hijau garlic to have a higher radical scavenging activity than the Lumbu Kuning variety.

The antioxidant properties of nine garlic varieties is shown in Table 3. It is showed that three local varieties namely Local Ncuna Sambori, Local Sangga Sembalun (white) and Local Lumbu Hijau were among the highest \% radical scavenging activities, while Egyptian variety was the lowest.

Based on the data in Table 3, garlic which has a high \% radical scavenging activity tends to contain a greater total phenolic. These causes the phenolic compounds to be oxidized by the Folin Ciocalteu reagent to become a phenolic ion to be large, therefore the phenolic ion formed will increase. The ion will reduce heteropoly acid and form a more concentrated blue compound complex. Further explains the technical reason in the laboratory that the blue color is more concentrated will result in a higher absorbance value so the phenolic number will be greater. Higher phenolic compounds is higher radical scavenging activity because the oxidation of Folin reagents results in blue.

Table 3. The Antioxidant Properties of Nine Garlic Varieties Which Were Purchased from Local Market in West Nusa Tenggara Province of Indonesia in 2018

\begin{tabular}{|c|c|c|c|}
\hline No & Varieties & $\begin{array}{c}\text { \% Radical Scavenging } \\
\text { Activity }\end{array}$ & $\begin{array}{c}\text { Phenolic content } \\
\text { (mg GAE/ g of garlic) }\end{array}$ \\
\hline 1 & Chinese (imported) & $66.62 \mathrm{~b}$ & $8.15 \mathrm{a}$ \\
\hline 2 & Egyptian (imported) & $50.26 \mathrm{a}$ & $8.05 \mathrm{a}$ \\
\hline 3 & Indian (imported) & $81.44 \mathrm{c}$ & $9.07 \mathrm{bc}$ \\
\hline 4 & Local Sangga Sembalun (purple) & $77.12 \mathrm{c}$ & $8.19 \mathrm{a}$ \\
\hline 5 & Local Sangga Sembalun (white) & $92.02 \mathrm{~d}$ & $8.99 \mathrm{ab}$ \\
\hline 6 & Local Sangga Nunggal & $83.28 \mathrm{c}$ & $8.22 \mathrm{a}$ \\
\hline 7 & Local Lumbu Kuning & $79.78 \mathrm{c}$ & $10.22 \mathrm{c}$ \\
\hline 8 & Local Lumbu Hijau & $91.55 \mathrm{~d}$ & $10.36 \mathrm{c}$ \\
\hline 9 & Local Ncuna Sambori & $92.24 \mathrm{~d}$ & $8.10 \mathrm{a}$ \\
\hline 10 & Ascorbic acids 15 ppm & $75.65 \mathrm{c}$ & \\
\hline
\end{tabular}


Moreover, the influence of farming inputs on the antioxidant properties of garlic (Sangga Sembalun white variety) is shown in Table 4. The table showed that different dose of farming inputs (P1, P2, P3, and P4) were not significantly influence the \% RSA and total phenolic compounds of harvested garlic. This is indicated that low input in garlic farming sistem would not directly decrease the quality of garlic both percentage of RSA and total phenolic. Unfortunately, the field research accomodate only one variety out of nine. Further investigation is needed for other varieties in order to gain general conclusion. Therefore cultivation of all varieties is needed in the future in order to gain valid conclusion on the influence of different dose of farming input toward quality of each garlic variety.

Table 4. The \% RSA and Total Phenolic on Garlic (Sangga Sembalun White Variety) with Different Dose of Farming Inputs Harvested from Field Experiment during the Growing Season in 2018

\begin{tabular}{|c|c|c|c|}
\hline No & Tretaments & \% Radical Scavenging Activity & Total Phenolic \\
\hline 1 & P1 & $85.5 \mathrm{ab}$ & $9.88 \mathrm{a}$ \\
\hline 2 & P2 & $92.28 \mathrm{~b}$ & $10.09 \mathrm{a}$ \\
\hline 3 & P3 & $95.40 \mathrm{~b}$ & $10.21 \mathrm{a}$ \\
\hline 4 & P4 & $96.36 \mathrm{~b}$ & $10.22 \mathrm{a}$ \\
\hline
\end{tabular}

\section{Acknowledgment}

These findings were taken from the report of the project entitled "Low input technological packages on garlic cultivation in West Nusa Tenggara Province of Indonesia" through the 2018 annual budget of the Institute for Assessment of Agricultural Technology (IAAT), West Nusa Tenggara Province, Indonesia. Many thanks to all team members for their support and dedication during the project implementation in 2018.

\section{References}

[1] Hilman, Y., Hidayat, A., \& Suwandi. (1997). Garlic cultivation in highland. Monograph No. 7. Indonesian Vegetables Research Institute. Indonesian Centre for Horticultural Research and Development. Indonesian Agency for Agricultural Research and Development (in Indonesian).

[2] Centre of Statistical Bureau. (2015). West Nusa Tenggara in Figures. Centre of Statictical Bureau, Republic of Indonesia (in Indonesian).

[3] Wibowo, S. (1990). Garlic Cultivation. Penebar Swadaya, Jakarta (in Indonesian).

[4] Randle, W. M. (2000). Increasing nitrogen concentration in hydroponic solutions affects onion flavour and bulb quality. Journal of the American Society of Horticultural Science, 125, 254-259.

[5] Brotnist, M. H., Pascale, J. V., \& Derslice, L. V. (1971). Flavour component of garlic extract. Journal of Agr. Food Chem, 19(2), 273-275.

[6] Sook, C., Cha, H. S., \& Le, Y. S. (2014). Physicochemical and antioxidant properties of black garlic. Molecules Open Access Journal, 19, 16811-16823.

[7] Xu, G., Ye, X., Chen, J., \& Liu, D. (2007). Effect of heat treatment on the phenolic compounds and antioxidant capacity of citrus peel extract. J. Agric. Food Chem, 55, 330-335.

[8] Francisco, M. L. L. D., \& Resureccion, A. V. A. (2009). Total phenolics and antioxidant capacity of heat-treated peanut skins. J. of Food Composition an Analysis, 22, 16-24.

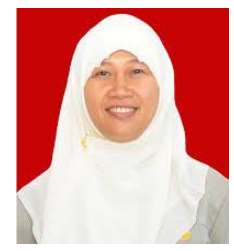

Ulyatu Fitrotin has completed her PhD from Gadjah Mada University, Yogyakarta, Indonesia in 2016 on post-harvest technology. Currently, she is the chairperson of the post-harvest research Division at the Institute for Assessment of Agricultural Technology (IAAT) West Nusa Tenggara Province, Indonesia. 
Baiq Nurul Hidayah has completed her PhD from School of Veterinary and Life Sciences, Murdoch University, Western Australia in 2018 with major in Biotechnology with the specialization of plant pathology. Currently, she is the chairperson of the Crop and Livestock Research Division at the Institute for Assessment of Agricultural Technology (IAAT), West Nusa Tenggara Province of Indonesia. 